\title{
The Human Computer Interaction in the Curricula of Mexican Higher Education Institutions
}

\author{
La interacción Humano Computador en el Currículo de las Instituciones de \\ Educación superior de México
}

\author{
N. J. Sánchez-Ramírez ; ; J. E. Muñoz-Rodríguez iD ; L. D. Rodríguez-Torres iD ; G. J. Cabrera-Reynaga ; \\ C. A. Collazos ; ; R. D. Estrada-Esponda iD \\ DOI: https://doi.org/10.22517/23447214.24496 \\ Artículo de investigación científica y tecnológica
}

\begin{abstract}
This article presents the actual state of the incorporation of HCI-related academic subjects to some Mexican universities' academic programs. The research approach was exploratory and descriptive, also having a quantitative scope. The research considered the $\mathbf{5 . 5 4 3}$ registered universities in all of Mexico in 2019. Results show that 1.266 universities offer undergraduate and technical programs in the Information and Communications Technology field, from which $\mathbf{4 2 . 5 8 \%}$ include 1.548 courses related to $\mathrm{HCI}$ in their academic programs that are part of 1.813 curricula. The courses were then classified into 10 categories proposed by the ACM/IEEE-CS "Joint Curriculum Task Force Computing Curricula". Additionally, in relation to human capital, it was found that $95.40 \%$ of the graduates of academic programs that include subjects related to HCI obligatorily had to pass these subjects and $4.30 \%$ had the possibility of taking elective subjects related to HCI. At the same time, after the review of 4 vacancy disclosure platforms, 24,827 job-related offers were found that in their specifications indicate skills and knowledge related to the HCI. This shows that Mexican universities have curricula that meet specific needs of the productive sector, at least in the field of HCI, which shows the importance of this area of knowledge in that country
\end{abstract}

Index Terms - Curriculum, HCI, Higher Education, HumanComputer Interaction, México.

Resumen-El artículo presenta el estado actual de la incorporación de asignaturas en el ámbito de la HCI (Interacción HumanoComputador) /IPO (Interacción Persona-Ordenador) en lo currículos de algunas universidades mexicanas. El enfoque de la investigación fue exploratorio y descriptivo además de tener un alcance cuantitativo. La investigación considero 5.543 universidades registradas para el 2019 en todo México. Los resultados reflejan que 1.266 universidades ofrecen programas académicos de Licenciatura Profesional y Tecnológica en el ámbito de las Tecnologías de la Información y la comunicación. De esas instituciones, el $\mathbf{4 2 . 5 8 \%}$ incluyen en sus currículos 1.548 asignaturas relacionadas con la HCI/IPO que hacen parte de 1.813 planes de estudio. Esas asignaturas fueron clasificadas en 10 categorías propuestas por el ACM/IEEE-CS “Joint Curricullum Task Force Computing Curriculla. Adicionalmente, en relación con el capital humano se encontró que el $95.40 \%$ de los graduados de programas académicos que incluyen asignaturas relacionadas con la HCI/IPO, de manera obligatoria tuvieron que aprobar dichas asignaturas y el $\mathbf{4 . 3 0 \%}$ tuvieron la posibilidad de tomar asignaturas optativas relacionadas con dicha área de conocimiento. Paralelamente, luego de la revisión de 4 plataformas de divulgación de vacantes se encontraron 24.827 ofertas relacionadas con empleos que en sus especificaciones señalan habilidades y conocimientos relacionados con la HCI/IPO. Esto evidencia que las universidades mexicanas tienen currículos que satisfacen necesidades específicas del sector productivo por lo menos en el ámbito de la HCI/IPO, lo cual muestra la importancia de dicha área de conocimiento en ese país

Palabras claves- Currículo, Educación Superior, HCI, Interacción Humano-Computador, México.

\section{INTRODUCTION}

$\mathrm{T}$ HE interaction processes that happens between humans and informatics systems with the purpose of contributing to the accomplishment of different activities, represents a challenge in various aspects [1] like ergonomics, accessibility and usability. Clear examples of said information systems are in the field of Information and Communication Technologies (ICT), that thanks to their significative growth, have generated the development of services that can potentially change their users' lives. However, some of this services or utilities generally available online are complex and hard to use for part of the population[2] by example to use mobiles apps, the cloud computing and artificial intelligence.

Therefore, an area of study in the context of computer science is Human-Computer Interaction (HCI), and in that figures important bodies of knowledge that include $\mathrm{HCI}$ as an important part in any process of software engineering, as in the case of SWEBOK [3], a body of knowledge of software engineering that dedicates a full chapter to $\mathrm{HCI}$ alone. In a joint manner, the 
ACM/IEEE-CS's report "Joint Curriculum Task Force Computing Curricula", proposed the HCI field as one of the 9 areas of professional IT training [4]. As well, some syllabus seek to guide the teaching of concepts and therefore the acquisition of skills in the field of HCI. However, there is still no consensus on the multiple topics that could be included in HCI courses, and therefore guidelines about how to teach these topics [5]. These kind of guides could be used as reference for training programs related to software engineering across the globe, as well as for the software industry in the extend that said guides mention which should be the IT workers technics, especially considering that these jobs increasingly involve skills related to specific new technologies, which makes it necessary for universities to address these skills in order to improve the level of employability.

The above states a correlation between the educators and of course, the software industry which receives professionals for the development of their productive activities. In fact, [6] mentions this correlation and in consequence, how HCI subjects must be included in universities' academic programs if what they intend is to form professionals with skills that help build up significantly the quality of areas like usability, accessibility and general aspects that help satisfy the user needs, or how its commonly called, the user experience (UX). All these skills are really useful to generate value in software developing companies, but are poorly developed in Latin-American context because of the constant redefinition or the lack of official concepts [4].

As a background in particular, it can be found that some Mexican Universities promote the teaching of HCI skills through videogames. Related with that, there was an intervention during the fifth semester of the Universidad de Colima, specifically for students in the software engineering program, where $95 \%$ of students expressed that they in fact acquired skills in the HCI field by videogames [5]. However, in the academic field, HCI also contributes to the teaching of other areas, for example languages. In [7] is observed how the HCI was used to promote the acquisition of competences about reading comprehension in English. Outside the academic field, there are $\mathrm{HCI}$ applications on things like interactive tours in a Mexican museum[8], [9] which makes necessary that universities start including courses that strengthen skills in this area. Additionally, different committees or associations across the world dedicate efforts to divulge technics and knowledge. In Mexican contexts, there's the ACM SIGCHI Mexico, that organizes an event called MexIHC [10], that has the purpose of divulging advances in the $\mathrm{HCI}$ field.

With the purpose of being able to map the current state of the HCI related academic programs offered in Mexico, an exploratory and descriptive study was carried out that included undergraduate programs in the field of Information and Communication Technologies (ICT).

This document is structured as follows: the methodology is presented initially, that covers the sampling frame, the target population and the information sources, then there are the conclusions and finally there are the references that support this research.

\section{RELATED STUDIES}

Similar studies had identified the grade in which skills, knowledge, and general concepts of $\mathrm{HCI}$ have been incorporated in the education of Iberoamerican countries. One of them included Colombian university programs, and managed to identify the development of academic programs with $\mathrm{HCI}$ subjects is barely incipient [6], based on the fact that the teaching in this discipline is just starting to show a consolidated formation process in undergraduate programs. The study showed that only $28.47 \%$ of the Colombian universities that had academic programs in the IT area, offered HCI related subjects, and that of all the students that graduate, only $4.36 \%$ had to take them in order to graduate. This situation coincides with what was commented in [4] because even if HCI should be one of the fundamental formation areas in professionals in the IT field, there are still not consolidated as fundamental subjects in universities programs. In the other hand, even though the development in this field is slow, at least in Colombia, there are important initiatives that encourage it, for example, the formation of research groups, organization of conferences and the inclusion of optative subjects at universities [11].

The interest for identifying the current state of the teaching of $\mathrm{HCI}$ in Latin America has included Mexico, in fact, in [1] is included in a revision to help cover all Spanish speakers located in North America. In this study published in 2008 is mentioned that both Mexico and Colombia incorporate few HCI subjects in their education programs. Nonetheless, in Mexico the HCI filed is more present, mainly because Mexico evaluates $\mathrm{HCI}$ in the CENEVAL test.

Similarly, other studies highlight the continuous effort referring the update on the HCI field and how convenient is to incorporate this types of disciplines in universities academic programs, especially with the goal of attending the diverse challenges that society constantly gives [4]. This paper also points out the effort that Latin America has done to consolidate this discipline, like the book titled "Interacción HumanoComputadora y aplicaciones en México" (Human-Computer Interaction and its applications in Mexico), which is part of a bigger collection, includes a complete study of HCI, such as the fundamentals, cognitive models and interaction, user-centered design, evaluation, among others [12]. Additionally, in the context of an open book initiative called LATIn, there is an entire book dedicated to design in HCI. This last work covers specific subjects like the rationale of $\mathrm{HCI}$ as a discipline, interaction design, user-centered design, prototyping technics, evaluation methods and even interface design for mobile devices [13]. Another book that has the purpose of supporting introductory HCI courses at universities, presents similar content to the previous ones [14].

Specifically, the work presented here differs from the works reviewed because a detailed search was carried out for the inclusion of HCI / IPO in university curricula, which translates 
into a valuable element to determine if there is a correspondence between the studies on the HCI / IPO (Book, articles) and precisely its implementation in the curricula.

\section{MeTHODOLOGY}

\section{A. Research approach and type}

With the purpose of identifying the amount of Mexican universities with academic programs that have subjects related with HCI, User Experience, Customer Experience, Usability and Accessibility, which are important to teach from the formation of professionals as well as other themes, practices and concepts to help in the construction in quality of informatics systems, and the correct implementation in productive sectors, and the use comfort for the final user, this research starts with an exploratory approach, which intended to address littlestudied, or even none-studied research problems in specific contexts [15]. Additionally, this approach contributes to determinate tendencies and identify potential relations between some variables [16].

Even though similar studies have been identified, this research involves solely the Mexican context, and emphasizes on all the active universities in the country. There is not any ranking or scale used to develop this study. In [17] its mentioned that exploratory studies have the purpose of diagnosing situations, meaning this kind of approach resulted in being the better one for this study. Secondary sources available in academic repositories or databases that were managed with Mendeley as a bibliographic reference manager were used as a data collection method.

As variables considered in the research, the import of HCI in the curricula of Mexican universities was established as a dependent variable, and the number of mandatory subjects and the number of elective subjects as independent variables.

Once the exploratory stage was finished and the data of the university's curricula was available, the descriptive stage started, which consisted in the recompilation, tabulation and analysis of the data; in fact, in [17] is added that the description is built from creative explorations.

Due to the nature of the study, it was not necessary to request the concept of an ethics committee, as the data presented here come from public sources of information on the institutional portals of Mexican universities. Population and Sample.
The population under study consisted of 5,343 Mexican universities active in the period of 2018-2019, according to the Asociación Nacional de Universidades e Instituciones de Educación Superior (ANUIES). The sampling frame consisted of the list of Mexican universities, as well as the list of the academic programs that the universities offered. The study was not probabilistic, because the revision phase only took in count the universities that had a web page available. Additionally, the fundamental unit of the study was determined by the universities that offered academic programs in the field of Information and Communication Technologies, according to the ANUIES. The recompilation of information consists of the lists and information on the Anuarios Estadístivos de Educación Superior, offer by the ANUIES as well, and in the web pages of the universities. These documents were the lists of active universities and the curricula of their academic programs. The classification that was proposed on the analysis stage [18] was very important, because it highlights that around HCI are fields and disciplines directly related to it that have important contributions for developing interactive, usable and accessible systems, in which people and their tasks are the principal objectives. These areas are Foundations, Designing Interaction, Programming Interactive Systems, User-Centered Design \& Testing, New Interactive Technologies, Collaboration \& Communication, Statistical Methods for HCI, Human Factors \& Security, Design-Oriented HCI y Mixed, Augmented and Virtual Reality. During the fieldwork, the authors independently reviewed the list of subjects and proceeded with their classification based on the subject's names, verifying their compatibility with the classification found in [18], this process was validated between peers, that is, by means of a triangulation exercise.

Finally, some job seeking web pages were consulted using different keywords that were chosen after studying the different academic programs. This strategy responds to a methodological triangulation approach, specifically in terms of information sources. This strategy refers to the application of several methods in the same research to collect information by contrasting the results, analyzing coincidences and differences.[19].

\section{RESULTS AND DisCUSSION}

Once all the Mexican universities portals were reviewed, it was found that from all 5.343 active Mexican universities in 2019, 1.266 offer academic programs related to Systems Engineering, Engineering informatics or in general related to the field of Communication and Information Technologies. Fig. 1 summarizes said results. 


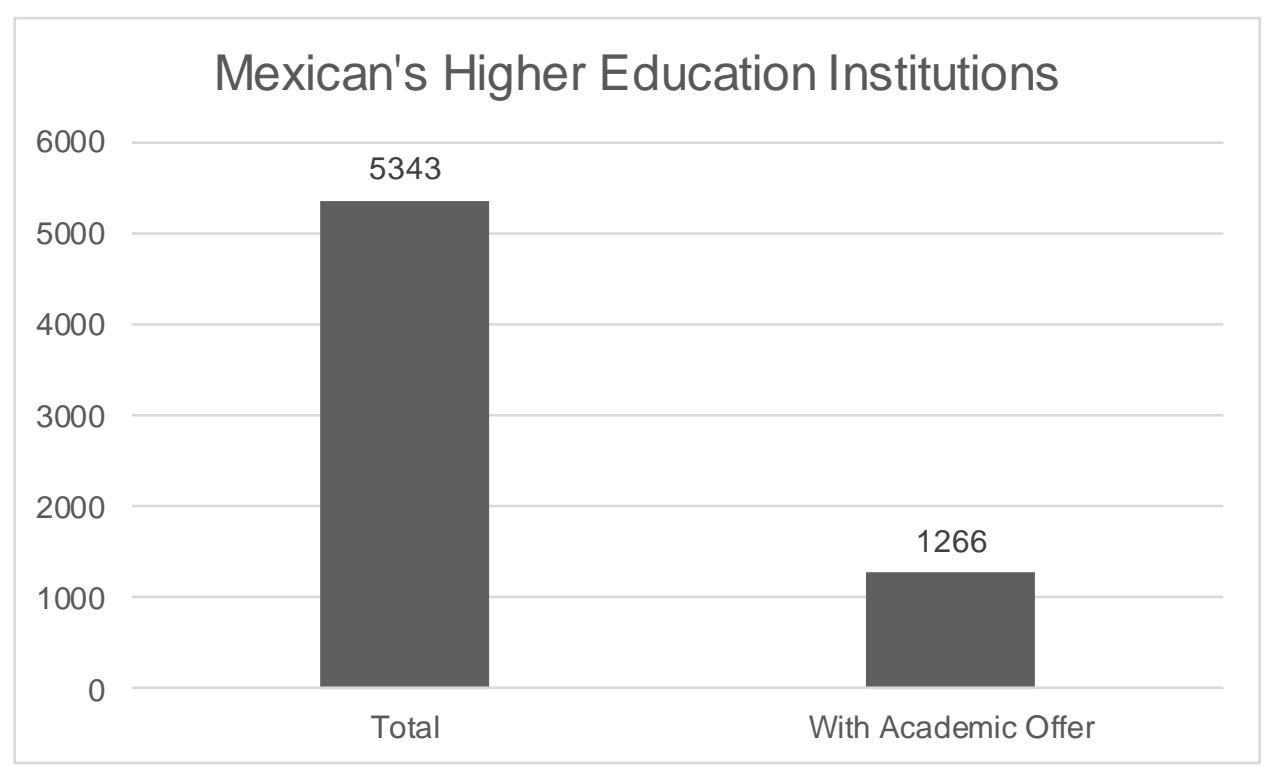

Fig. 1.Mexican's Higher education institutions

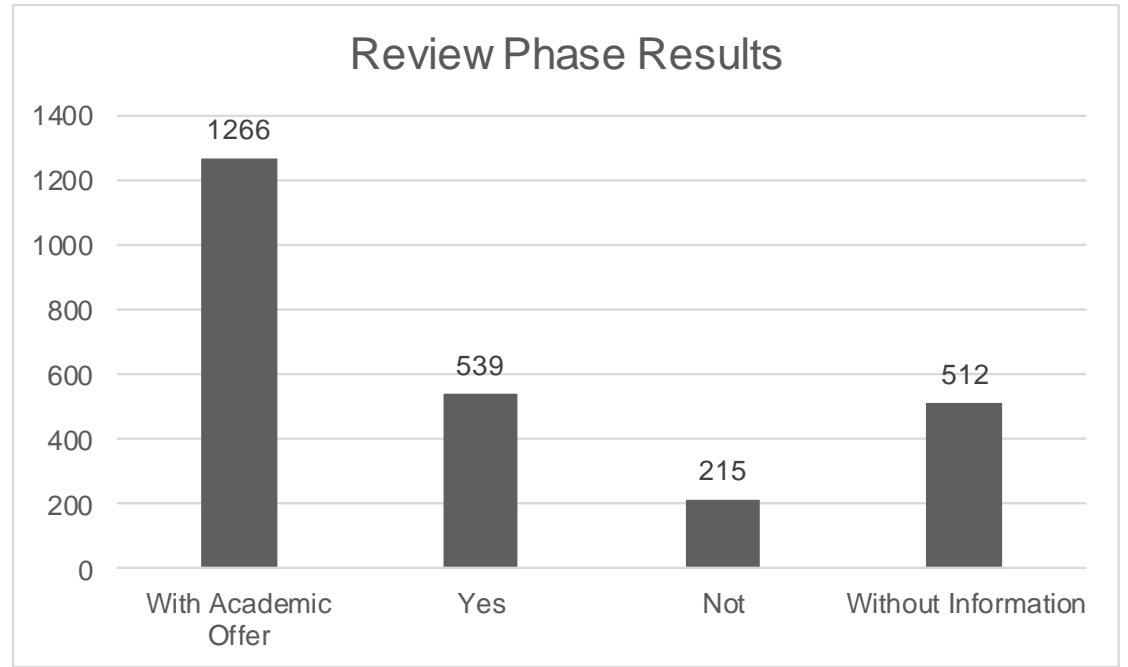

Fig. 2. Review Phase Results

Of the 1.266 universities with the academic programs mentioned before, 539 have subjects related to HCI, 215 don't have any relation, and from 512 was not possible to verify because their curricula or the web portal of the university was not available. Fig. 2 shows the verification.
In terms of subjects, 2.944 that were included on the 1.813 curricula were evaluated, from which 1.548 were related to HCI, 596 were not, and in 800 cases was not possible to verify because of the mentioned motives. Additionally, this 1548 were grouped in 177 different denominations and then classified in 10 categories proposed by the la ACM/IEEE. The Table I presents one subject by each category. 
TABLE I

SUBJECTS PER CATEGORY

\begin{tabular}{|c|c|c|c|c|c|}
\hline University & Type University & Academy Program & Subject & Category & Mandatory \\
\hline $\begin{array}{l}\text { Instituto } \\
\text { Universitario } \\
\text { Amerike }\end{array}$ & Private & $\begin{array}{l}\text { Licenciatura en } \\
\text { Desarrollo de } \\
\text { Software Interactivo } \\
\text { y Videojuegos }\end{array}$ & $\begin{array}{l}\text { Desarrollo de } \\
\text { Interfaces para } \\
\text { Aplicaciones } \\
\text { Móviles }\end{array}$ & $\begin{array}{l}\mathrm{HCI} / \mathrm{New} \\
\text { Interactive } \\
\text { Technologies }\end{array}$ & $\mathrm{Y}$ \\
\hline $\begin{array}{l}\text { Universidad } \\
\text { Tecnológica de } \\
\text { Tijuana }\end{array}$ & Public & $\begin{array}{l}\text { Ingeniería en } \\
\text { Tecnología de } \\
\text { Información y } \\
\text { Comunicación: Área } \\
\text { Entornos Virtuales y } \\
\text { Negocios Digitales }\end{array}$ & $\begin{array}{l}\text { Desarrollo de } \\
\text { Aplicaciones de } \\
\text { Realidad } \\
\text { Aumentada }\end{array}$ & $\begin{array}{l}\text { HCI/Mixed, } \\
\text { Augmented and } \\
\text { Virtual Reality }\end{array}$ & $\mathrm{Y}$ \\
\hline $\begin{array}{l}\text { Universidad } \\
\text { Autónoma de Baja } \\
\text { California }\end{array}$ & Private & $\begin{array}{l}\text { Ingeniería en } \\
\text { Computación }\end{array}$ & $\begin{array}{l}\text { Diseño de } \\
\text { Interacciones }\end{array}$ & $\begin{array}{l}\mathrm{HCI} / \text { Designing } \\
\text { Interaction }\end{array}$ & Y \\
\hline $\begin{array}{l}\text { Universidad Juárez } \\
\text { Autónoma de } \\
\text { Tabasco }\end{array}$ & Public & $\begin{array}{l}\text { Licenciatura en } \\
\text { Informática } \\
\text { Administrativa }\end{array}$ & $\begin{array}{l}\text { Interacción } \\
\text { Hombre-Máquina }\end{array}$ & HCI/Foundations & Y \\
\hline $\begin{array}{l}\text { Instituto Tecnológico } \\
\text { Superior de } \\
\text { Zacatecas Occidente }\end{array}$ & Public & $\begin{array}{l}\text { Ingeniería en } \\
\text { Sistemas } \\
\text { Computacionales }\end{array}$ & $\begin{array}{l}\text { Lenguajes de } \\
\text { Interfaz }\end{array}$ & $\begin{array}{l}\mathrm{HCI} / \text { Programming } \\
\text { Interactive Systems }\end{array}$ & $\mathrm{Y}$ \\
\hline $\begin{array}{l}\text { Universidad } \\
\text { Autónoma de } \\
\text { Chiapas }\end{array}$ & Public & $\begin{array}{l}\text { Licenciatura en } \\
\text { Ingeniería en } \\
\text { Desarrollo y } \\
\text { Tecnologías del } \\
\text { Software }\end{array}$ & $\begin{array}{l}\text { Interfaces Humano } \\
\text { Computadora }\end{array}$ & $\begin{array}{l}\text { HCI/Design- } \\
\text { Oriented HCI }\end{array}$ & $\mathrm{Y}$ \\
\hline $\begin{array}{l}\text { Instituto Tecnológico } \\
\text { Superior de Acatlán } \\
\text { de Osorio }\end{array}$ & Public & $\begin{array}{l}\text { Ingeniería en } \\
\text { Informática }\end{array}$ & $\begin{array}{l}\text { Usabilidad y } \\
\text { Pruebas de } \\
\text { Software }\end{array}$ & $\begin{array}{l}\text { HCI/User-Centered } \\
\text { Design \& Testing }\end{array}$ & $\mathrm{Y}$ \\
\hline $\begin{array}{l}\text { Universidad } \\
\text { Interamericana del } \\
\text { Norte }\end{array}$ & Private & $\begin{array}{l}\text { Licenciatura en } \\
\text { Ingeniería Industrial } \\
\text { y de Sistemas }\end{array}$ & Ergonomía & $\begin{array}{l}\mathrm{HCI} / \text { Human } \\
\text { Factors \& Security }\end{array}$ & $\mathrm{Y}$ \\
\hline Instituto SAE & Private & $\begin{array}{l}\text { Licenciatura en } \\
\text { Diseño de } \\
\text { Videojuegos }\end{array}$ & $\begin{array}{l}\text { Diseño de } \\
\text { Experiencias }\end{array}$ & $\begin{array}{l}\text { HCI/Collaboration } \\
\& \text { Communication }\end{array}$ & $\mathrm{Y}$ \\
\hline $\begin{array}{l}\text { Universidad } \\
\text { Mesoamericana de } \\
\text { San Cristóbal }\end{array}$ & Private & $\begin{array}{l}\text { Licenciatura en } \\
\text { Informática }\end{array}$ & $\begin{array}{l}\text { Método de Análisis } \\
\text { y Diseño de Sistema } \\
\text { de Información }\end{array}$ & $\begin{array}{l}\text { HCI/Statistical } \\
\text { Methods for HCI }\end{array}$ & Y \\
\hline
\end{tabular}

In a first review there were 1.826 subjects selected that were related to $\mathrm{HCI}$, however based on the denomination and categorization some of them were discarded, like Análisis y Diseño or Diseño de Sistemas. Even if it is true that they refer to an important phase in software development, they don't necessarily relate to HCI specifically, like design, which could be referring to Data Design, Architecture Design or some other structural or technical practice. The Fig. 3 shows the classification done to the 177 identified subjects in each of the ACM/IEEE categories. 


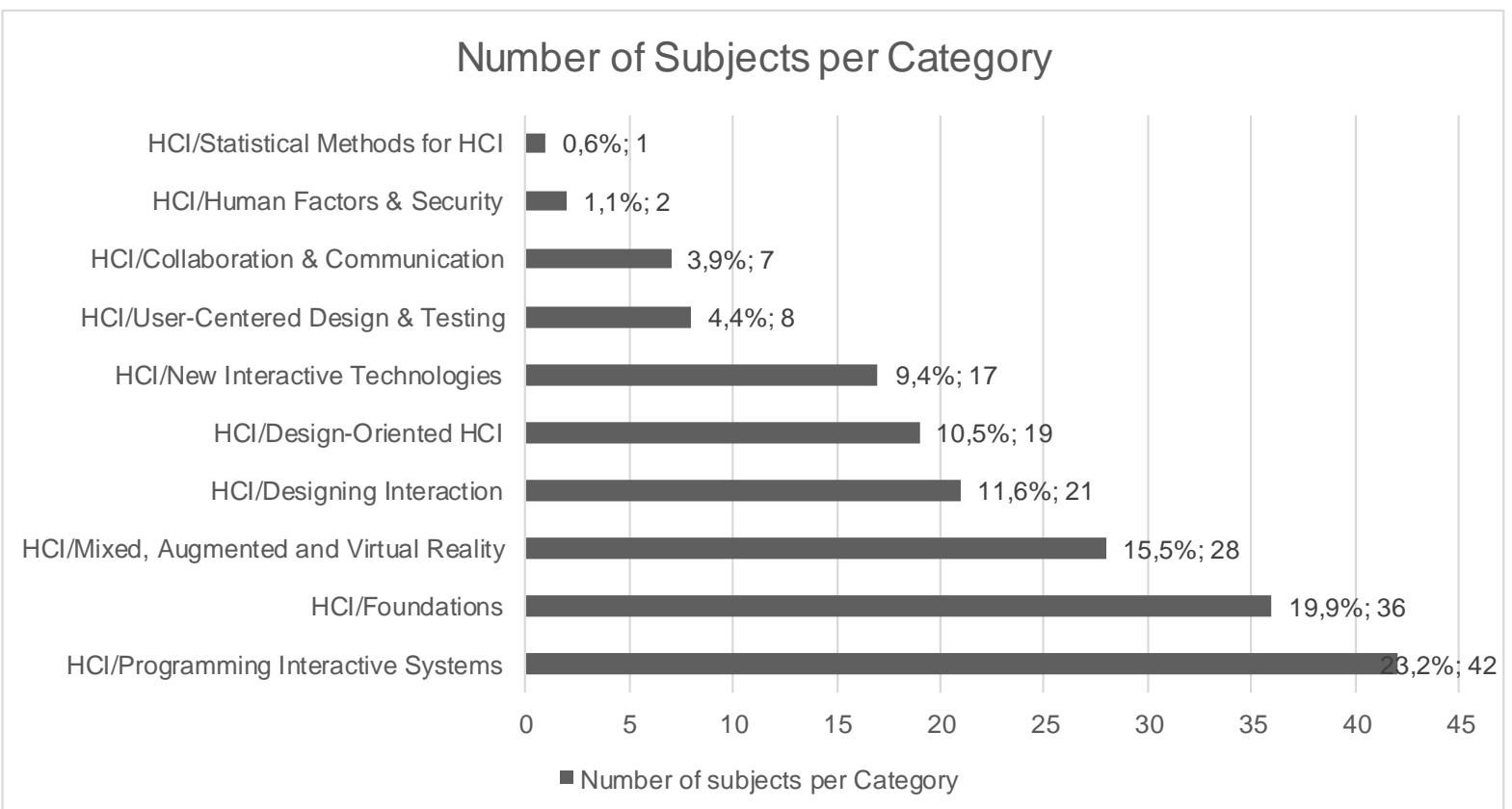

Fig. 3. Number of subjects per category

In terms of Human Capital, it was possible to identify that in the 1.266 universities with academic programs under analysis, 22.948 graduated in 2019. From those, 11.663 graduated from universities that had academic programs with subjects related to HCI, 5.441 did not had HCI subjects on their curricula, and for 5.844 of the graduated was not possible to review their curricula. Now, in terms of the graduated alumni from academic programs with subjects related to HCI, it was found that from the $11.633,11.126$ had to take those subjects mandatorily, while 502 had the chance to choose whether to take them or not. For 35 of them was not possible to determine if they could choose. The above states that the $48.48 \%$ of the graduated in 2019 have knowledge referring to HCI, which without a doubt puts Mexico as a country that gives significative importance to this discipline. Table II shows this data. Even compared to the study conducted in Colombia [6], it can be observed that in the case of that country only $4.36 \%$ of the graduates had to take compulsory courses, while based on the results presented here, in Mexico $95.4 \%$ of the graduates had to take compulsory courses. TABLE II

GRADUATES WITH KNOWLEDGE HCI

\begin{tabular}{|c|c|c|c|c|}
\hline & $\begin{array}{l}\text { Of universities with } \\
\text { offer HCI/IPO }\end{array}$ & $\begin{array}{l}\text { Of universities } \\
\text { without offer } \\
\text { HCI/IPO }\end{array}$ & Without Information & Total \\
\hline Graduates & 11.663 & 5.541 & 5.844 & 22.948 \\
\hline \multirow{2}{*}{ Mandatory } & Yes & Not & Without Information & \\
\hline & 11.126 & 502 & 35 & 11.663 \\
\hline $\begin{array}{l}\% \text { with respect to all } \\
\text { graduates }\end{array}$ & 48.48 & 2.19 & 0.15 & \\
\hline $\begin{array}{l}\% \text { with respect to all } \\
\text { university graduates with } \\
\text { an offer }\end{array}$ & 95.40 & 4.30 & 0.30 & \\
\hline
\end{tabular}

To complement the revision phase, some job seeking web pages were consulted using different keywords that were obtained after the different curricula review. Fig. 4 reflects each platform results. The keyword used where UX, UI, Usabilidad (Usability), Diseño de Interacción (Interaction Design), among others. 


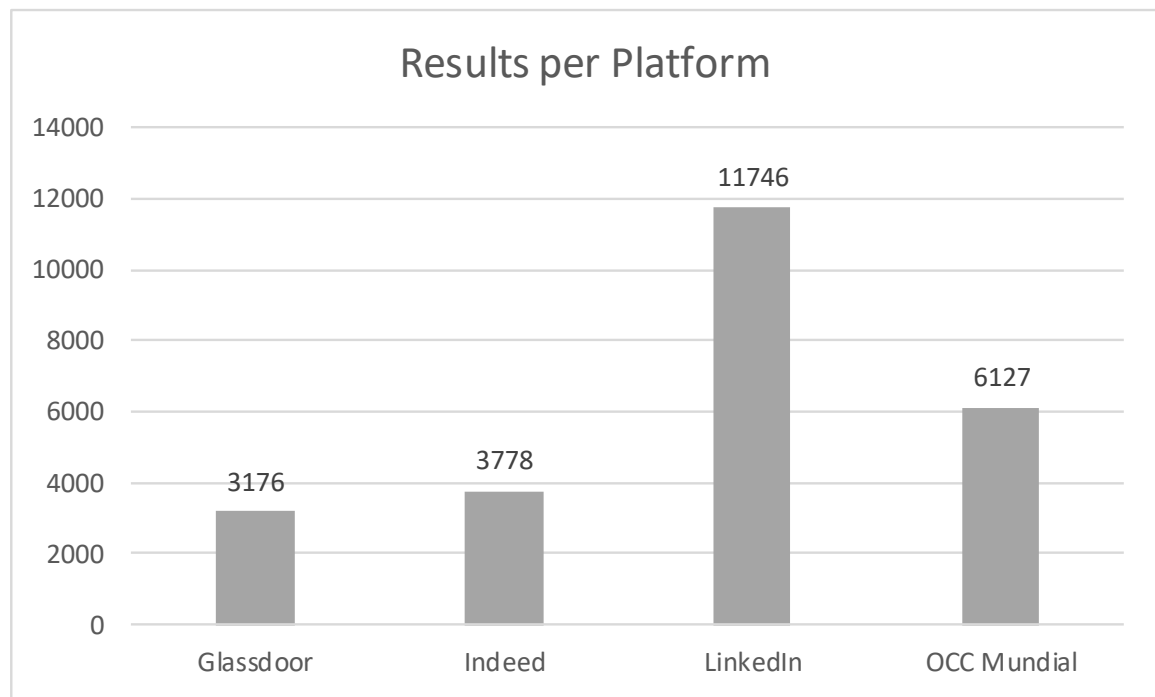

Fig. 4. Results per platform

TABLE III

RESULTS PER POSITION

\section{Position}

Vacancies

Desarrollador de Visión Computacional (Computational Vision Developer)

Desarrollador de Realidad Aumentada (Augmented Reality Developer)

Diseñador (Designer)

Programador de Realidad Aumentada y Virtual (Virtual and Augmented Reality Progammer)

Diseñador de Interacción (Interaction Designer)

Diseño Web (Web Design)

Gerente UX (UX Manager)

Desarrollador Front End (Front end Developer)

Consultor UX (UX Consultor)

Desarrollador UX (UX Developer)

Diseñador UI (UI Designer)

Programador de Realidad Virtual y Aumentada (Augmented and Virtual Reality Progammer)

Diseñador Web (Web Designer)

Redactor UI (UI Writer)

Ingeniero de UI (UI Engineer)

Estratega de Contenido UX (UX Content Strategist)

Desarrollador de UI (UI Developer)

Desarrollador Unity (Unity Developer)

Diseñador Gráfico (Graphic Designer)

Director UX (UX Director)

Desarrollador UI (UI Developer)

Consultor UX/UI (UX/UI Consultor)

Desarrollador Front end (Front end Developer)

Diseñador UX/UI (UX/UI Designer) 


\begin{tabular}{|c|c|}
\hline Position & Vacancies \\
\hline Diseñador UX (UX Designer) & 3.484 \\
\hline Investigador UX (UX Researcher) & 3.881 \\
\hline Total & 24.827 \\
\hline
\end{tabular}

The review of said platforms also facilitated the study of some vacancies by the role or positions required, it was common to find vacancies for Developers and User Experience Managers, UI Designer or Engineer, as well as UX/UI Consultor. In total there were 24.827 vacancies due to August 9, 2020. Table III presents the amount of vacancies for each denomination found with the used keywords.

Additionally, is presented the amount of vacancies by each used keyword. Fig. 5 shows the results consolidated by keyword.

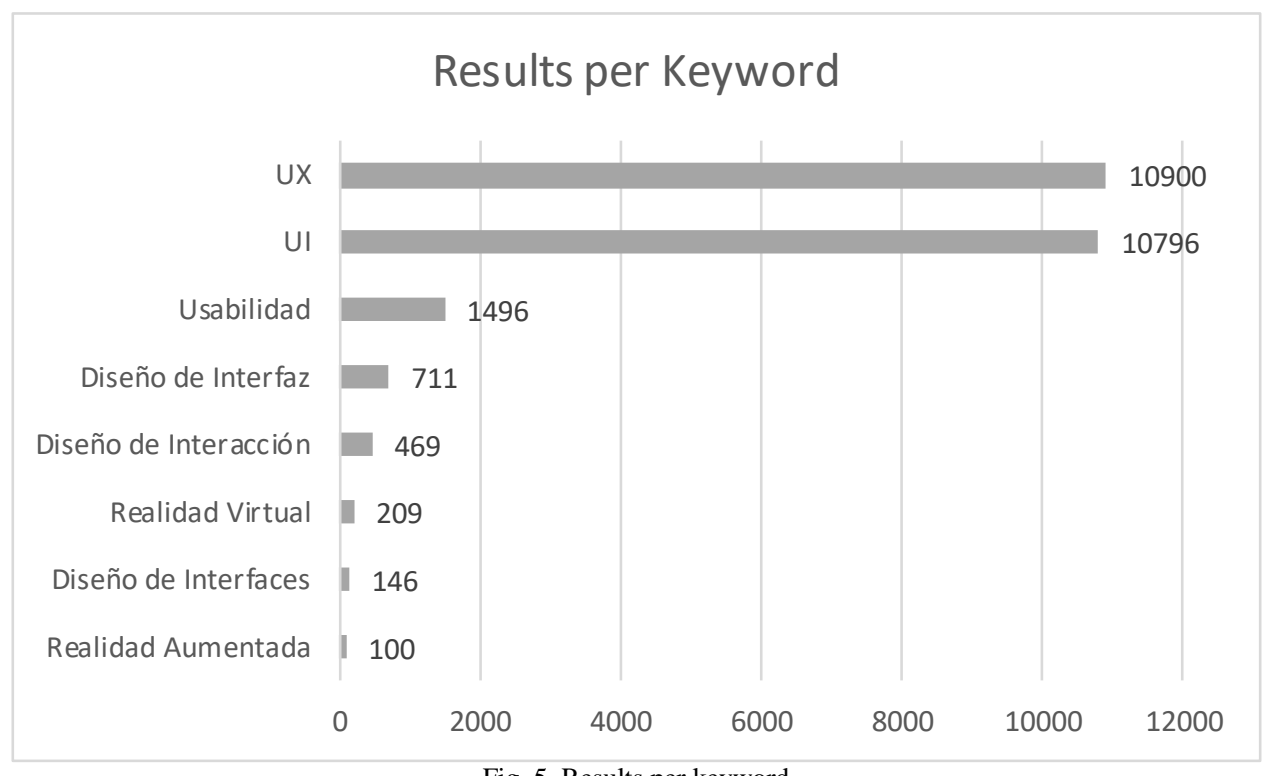

Fig. 5. Results per keyword

In the context of the categories proposed by the ACM/IEEE, it was found that the $\mathrm{HCI} /$ Designing Interaction category includes some subjects denominated as Graficación (Graphing) that in the review phase was found that this refers to UI Design. This term is not common in other countries like Colombia, where similar studies have been done.

On the other hand, in the HCI/New Interactive Technologies category was common to find subjects in the context of mobile development; however, in some cases the subject does not really fully state its relation to HCI, but still can be considered that they sporadically addresses related issues. For example, there are subjects like Desarrollo de interfaces para Aplicaciones Móviles (Interface Development for Mobile Devices) that explicitly reflect their relation to HCI, but there are also some like Diseño de Aplicaciones para Dispositivos Móviles (Application Design for Mobile Devices) that don't really show a direct relation to HCI, even though they suggest the approach to some subjects of the area.
For the HCI/Mixed, Augmented and Virtual Reality category 28 subjects were found, with denominations like Desarrollo de Aplicaciones de Realidad Virtual (Virtual Realty Applications Development) and Diseño de Interfaces, Multimedia y Realidad Virtual (Interface Design, Multimedia and Virtual Reality); this is related to the data obtained from the job seeking platforms, because this platforms show positions like Programador de Realidad Virtual y Aumentada (Augmented and Virtual Reality Programmer) and Desarrollador de Realidad Aumentada (Augmented Reality Developer), meaning that there is actually coherence between the academic formation and the actual market demand in terms of HCI skills, specifically in Virtual Reality and other related systems.

Of all the categories proposed by the ACM/IEE, $\mathrm{HCI} /$ Statistical Methods for HCI was the one with the least mentioned in the obtained results. The subject Método de Análisis y Diseño de Sistema de Información (Analysis Method and Information Systems Design) was classified there because of all the subjects analyzed this one referenced the study of techniques with quantitative approach. In fact, in the ACM/IEEE guide, its mentioned that this type of formation or 
concepts (statistics, quantitative approaches) are more commonly found in other fields, like psychology.

In the HCI/Programming Interactive Systems were classified subjects like Patrones de Diseño de Software (Software Design Patterns), Desarrollo Web Front End (Front End Web Development), Programación de Interfaces Web (Web Interfaces Programming) among others subjects that show an explicit relation to activities at a programming level, starting by design patterns and with an specialized approach to Front End. The $23.2 \%$ of all studied subjects were associated to this category.

In the $\mathrm{HCI} /$ Foundations were found subjects like Hombre Computadora (Human Computer), Interfaces Hombre Máquina e Interacción Humano Computador (Human Machine Interfaces and Human Computer Interaction). In total, 36 subjects were grouped in this category, representing the $19.9 \%$ of all the studied subjects. These subjects encourage the acquisition of a disciplinary vocabulary about HCI because the introduce subjects like conceptual models, feedback, and affordance.

The presented categories represent the $90 \%$ of the categorized subjects. In an analysis done to all these subjects was found a tendency to 3 specific subjects: Inteligencia Artificial (Artificial Intelligence), Graficación (Graphing), Lenguajes de Interfaz (Interface Languages) that accumulate more than the $50 \%$ of the 171 with different denominations, which suggests a clear trend for the $\mathrm{HCI} / \mathrm{New}$ Interactive Technologies and $\mathrm{HCI} /$ Programming Interactive Systems groups.

\section{CONCLUSIONS AND FUTURE WORK}

It is evident that interest in HCI/IPO has increased notably in Mexico, this is demonstrated by the results presented in [1] and the results here obtained. Additionally, all subjects identified could be classified in the categories of the ACM/IEE. However, as future work could propose analyze in detail of the study plans, with reach to the bibliographic references thereof, thus identifying whether there is a consensus on the approach of the area from undergraduate academic programs. At the same time, state test results could be reviewed to validate whether the competencies of the HCI/IPO discipline were consolidated in the formative process.

In studies with Iberoamerican reach [1] a good number of countries is evaluated. However, this exercise could be replicated in some of these countries in order to provide a more detailed mapping on the inclusion of HCI/IPO-related subjects in academic programs on information and communication technologies (ICT). Specifically compared with the study conducted in Colombia, it is observed that in this country only $16.05 \%$ of the universities that offer IT programs include $\mathrm{HCI} / \mathrm{IPO}$-related subjects in their curricula. While for the Mexican case it was found that such level of inclusion amounts to $43 \%$, which implies that in relation to the research question the HCI/IPO area is more relevant in Mexico than in Colombia.
The process of reviewing curriculums was challenging, the latter because some universities put little attention to their institutional portals so that they are not available or are outdated. This implies that future studies should include field work related to techniques such as focus groups or bivariate analysis.

There is a correspondence between academic works on HCI / IPO specifically at the conceptual level and the curricula, that is, it is possible to affirm that universities have conceptual contributions to continue strengthening the training of their students in skills in the Human-Computer Interaction scenario, an example are the detailed works in [12] and [14].

The work needs in terms of HCI/IPO competencies are broad. In addition, universities with program offerings in the field of ICT contribute significantly to the satisfaction of such vacancies, as they offer obligatory and also optional subjects associated with HCI which generates a university-company coherence.

Finally, although the fieldwork involved in the conduct of questionnaires, interviews and in general methods at the qualitative level, turns out to be dispended by the need for the availability of groups of interest to consult, it would be important to develop such work that complements these quantitative results and thus explain the phenomena that motivate the offer or not of subjects related to the HCI/IPO of methodological triangulation.

\section{ACKNOWLEDGMENT}

This work is presented during the 25th summer of the Pacific Scientific Investigation and Technology DELFÍN (Version 2020). Thanks to that space it was possible to join all efforts to bring together this successful investigation.

\section{REFERENCES}

[1] T. Granollers, C. A. Collazos, and M. P. González, "The state of HCI in Ibero-American countries," J. Univers. Comput. Sci., vol. 14, no. 16, pp. 2599-2613, 2008, doi: 10.3217/jucs-014-16-2599.

[2] L. García, A. Pernett, and J. Cano, "Estudio exploratorio de usabilidad para niños de Colombia,” Zo. Próxima, no. 26, pp. 12-30, 2017, doi: 10.14482/zp.22.5832.

[3] I. C. Society, Guide to the Software Engineering Body of Knowledge Version 3.0 (SWEBOK Guide V3.0). .

[4] R.-M. Gil, J.-M. Gonzalez-Calleros, C.-A. Collazos, and C.-S. Gonzalez-Gonzalez, "Análisis de las titulaciones formales e informales en Iberoamérica de UX: desafíos para la formación online Análisis de las titulaciones formales e informales en Iberoamérica de UX: desafíos para la formación online Analysis on formal and informal quali," no. July, 2020, doi: 10.13140/RG.2.2.35474.27842.

[5] P. C. Santana-Mancilla, M. A. Rodriguez-Ortiz, M. A. Garcia-Ruiz, L. S. Gaytan-Lugo, S. B. Fajardo-Flores, and J. Contreras-Castillo, "Teaching HCI skills in higher education through game design: A study of students' perceptions," Informatics, vol. 6, no. 2, pp. 1-12, 2019, doi: 10.3390/informatics6020022.

[6] R. D. Estrada-Esponda, C. A. Riascos-Pareja, and Á. A. LoaizaDuque, "La interacción humano computador en el currículo de las instituciones de educación superior de Colombia," Rev. Investig. 
Desarro. E Innovación, vol. 9, no. 1, pp. 147-162, 2018, doi: 10.19053/20278306.v9.n1.2018.7722.

[7] M. Y. Mejia-sierra, J. S. Pinto, M. S. Avila-garcia, and M. I. Vázquez-de-la-rosa, "Uso de interacciones humano-computadora para la recopilación de datos del proceso de lectura de comprensión de textos técnicos en inglés," vol. 1, pp. 37-38, 2016.

[8] R. Rosales et al., "Modelling the interaction levels in HCI using an intelligent hybrid system with interactive agents: A case study of an interactive museum exhibition module in Mexico," Appl. Sci., vol. 8, no. 3, pp. 1-21, 2018, doi: 10.3390/app8030446.

[9] R. Rosales, M. Castañón-Puga, F. Lara-Rosano, R. D. Evans, N. Osuna-Millan, and M. V. Flores-Ortiz, "Modelling the interruption on HCI using BDI agents with the fuzzy perceptions approach: An interactive museum case study in Mexico," Appl. Sci., vol. 7, no. 8, pp. 1-18, 2017, doi: 10.3390/app7080832.

[10] "CHI-Mexico: Ten years of the Mexican Conference on HCI $\mid$ ACM Interactions," interactions, 2017. https://interactions.acm.org/archive/view/november-december2017/chi-mexico (accessed Jul. 08, 2020).

[11] C.-A. Collazos, J. Hurtado, P. Magé, and F. Pino, "Investigación de HCI en Colombia: Perspectiva del Grupo IDIS," Rev. Digit. Aipo, vol. 24, no. 5, pp. 207-209, 1972.

[12] L. A. Castro and M. D. Rodríguez, Interacción HumanoComputadora y Aplicaciones en México. .

[13] C. E. Collazos, Temas de Diseño en interacción HumanoComputador. .

[14] J. Muñoz Arteaga, J. M. González Calleros, and A. Sánchez Huitrón, "La Interacción Humano-Computadora en México," p. 368, 2015.

[15] P. Cazau, "Introducción a la Investigación en Educación.," p. 194, 2006.

[16] D. Causas, "Definición de las variables , enfoque y tipo de investigación," Univ. Nac. Abierta y a Distancia, pp. 1-11, 2005, [Online]. Available: http://www.mecanicahn.com/personal/marcosmartinez/seminario1/l os_pdf/l-Variables.pdf.

[17] J. L. Abreu, "Hipótesis, Método \& Diseño de Investigación," Daena Int. J. Good Conscienc., vol. 7, no. 2, pp. 187-197, 2012.

[18] IEEE and ACM, CS2013: Computer Science Curricula 2013, vol. 48, no. 3. 2015.

[19] S. Aguilar Gavira and J. Barroso Osuna, "La triangulación de datos como estrategia en investigación educativa," Píxel-Bit, Rev. Medios y Educ., no. 47, pp. 73-88, 2015, doi: 10.12795/pixelbit.2015.i47.05.

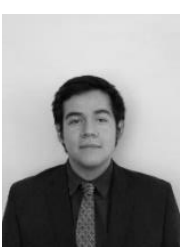

Sánchez Ramírez Nicolás De Jesús graduated from the Universidad de la Salle Bajío Campus Campestre in the 2017-2021 generation as a Software and Computer Systems Engineer. His interests include back-end focused software development, mobile platform development and database management. He currently works as a full-time developer in Mexico City for the company Dictum. ORCID: https://orcid.org/0000-0001-6554-5763.

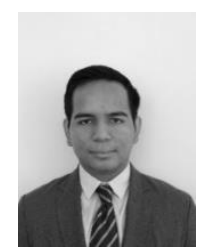

Muñoz Rodríguez Jonathan Eduardo graduated from Universidad de la Salle Bajío Campus Campestre as a Software and Computer Systems Engineer. His interests include software development, focused on the field of user experience and graphical interface (Front-end).

ORCID: https://orcid.org/0000-0003-1170-1972

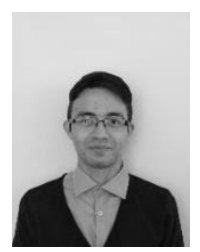

Rodríguez Torres Luis Daniel graduated from Universidad de la Salle Bajío Campus Campestre as a Software and Computer Systems Engineer. His interests include software quality, as well as technology project management.

ORCID: https://orcid.org/0000-0001-5830-7484

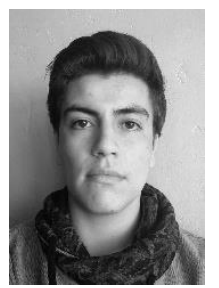

Cabrera Reynaga Gerardo Javier graduated from Universidad de la Salle Bajío Campus Campestre as a Software and Computer Systems Engineer. Interested in User Experience, User Interface, web and mobile development. Currently working as a full time front end developer.

ORCID: https://orcid.org/0000-0002-0217-6312

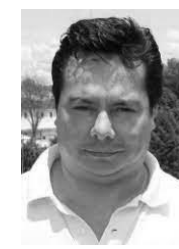

César A. Collazos, full professor computer science department at Universidad del CaucaColombia. Phd in computer science and head of IDIS research group at Universidad del Cauca. Leader of HCI-Collab (Iberoamerican network supporting hci teaching ). His main research areas include: Human Computer Interaction, Computer Supported Collaborative Learning, ICT in education. ORCID: https://orcid.org/0000-0002-7099-8131

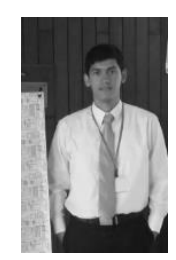

Royer David Estrada-Esponda, Software deveplomer and full time professor at Universidad del Valle at Tuluá. Also I have a Master in Evaluation and Management project and my skills English are intermediate. Currently my focus is the knowlegde management, software deveploment, Project Management, UX and Education ORCID: https://orcid.org/0000-0002-6849-1278 